\title{
The concept of "self-organization" in the context of modern education
}

\section{O conceito de "auto-organização" no contexto da educação moderna}

\section{El concepto de "autoorganización" en el contexto de la educación moderna}

\author{
Yana Vladimirovna Kryucheva ${ }^{1}$ (i), Irina Vasilievna Tolstoukhova ${ }^{1}$ iD \\ ${ }^{1}$ Industrial University of Tyumen, Tyumen, Russia. \\ Corresponding author: \\ Yana Vladimirovna Kryucheva \\ Email: yanakryucheva@mail.ru
}

How to cite: Kryucheva, Y.V., \& Tolstoukhova, I.V. (2022). The concept of "self-organization" in the context of modern education. Revista Tempos e Espaços em Educação, 15(34), e17213. http://dx.doi.org/10.20952/revtee.v14i33.17213

\begin{abstract}
The article focuses on the issue of developing the sixth universal competence proposed in the Federal State Educational Standard 3++, which aims at the development of self-organization skills the ability to plan one's activities in the short, medium, and long term and manage time with consideration of one's capabilities and physical energy. The study offers an analysis of the results of a diagnostic study of the level of learning organization in students at a technical university. The authors propose their perspective on the concept of self-organization of learning. The stages of students' self-organization of learning activities within the framework of the academic discipline "Fundamentals of self-organization and self-study" are identified as the motivational component, the personality component, the practical component, and the reflection component. The significance of the proposed stages is substantiated, and their content is disclosed. The main methods employed in the study include the theoretical methods of analysis, summarization, classification, and the study of psychological and pedagogical literature, and the empirical methods of observation, recording empirical data, statistical data processing, tests, and the interpretation of a person's inner world. The results of the study can be of use to teachers and psychologists and be put into practice as part of psychological counseling for students.
\end{abstract}

Keywords: Self-organization. Learning activities. Goal setting. Motivation. Planning. Reflection.

\section{RESUMO}

O artigo enfoca a questão do desenvolvimento da sexta competência universal proposta na Norma Educacional Estadual Federal 3++, que visa o desenvolvimento de habilidades de auto-organização - a capacidade de planejar suas atividades a curto, médio e longo prazo e gerenciar o tempo levando em consideração suas capacidades e energia física. O estudo oferece uma análise dos resultados de um estudo diagnóstico do nível de organização da aprendizagem em estudantes de uma 
universidade técnica. Os autores propõem sua perspectiva sobre o conceito de auto-organização da aprendizagem. As etapas da auto-organização dos alunos das atividades de aprendizagem no âmbito da disciplina académica "Fundamentos da auto-organização e auto-estudo" são identificadas como a componente motivacional, a componente de personalidade, a componente prática e a componente de reflexão. O significado das etapas propostas é fundamentado e seu conteúdo é divulgado. Os principais métodos empregados no estudo incluem os métodos teóricos de análise, sumarização, classificação e o estudo da literatura psicológica e pedagógica, e os métodos empíricos de observação, registro de dados empíricos, processamento de dados estatísticos, testes e a interpretação dos dados de uma pessoa. mundo interior. Os resultados do estudo podem ser úteis para professores e psicólogos e ser colocados em prática como parte do aconselhamento psicológico para estudantes.

Palavras-chave: Auto-organização. Aprendendo atividades. Definição de metas. Motivação. Planejamento. Reflexão.

\section{RESUMEN}

El artículo se centra en la cuestión del desarrollo de la sexta competencia universal propuesta en el Estándar Educativo del Estado Federal 3++, que tiene como objetivo el desarrollo de habilidades de autoorganización: la capacidad de planificar sus actividades a corto, mediano y largo plazo y administrar el tiempo teniendo en cuenta las propias capacidades y la energía física. El estudio ofrece un análisis de los resultados de un estudio diagnóstico del nivel de organización del aprendizaje en estudiantes de una universidad técnica. Los autores proponen su perspectiva sobre el concepto de autoorganización del aprendizaje. Las etapas de la autoorganización de las actividades de aprendizaje de los estudiantes en el marco de la disciplina académica "Fundamentos de la autoorganización y el autoestudio" se identifican como el componente motivacional, el componente de personalidad, el componente práctico y el componente de reflexión. Se fundamenta el significado de las etapas propuestas y se divulga su contenido. Los principales métodos empleados en el estudio incluyen los métodos teóricos de análisis, resumen, clasificación y el estudio de la literatura psicológica y pedagógica, y los métodos empíricos de observación, registro de datos empíricos, procesamiento de datos estadísticos, pruebas e interpretación de la personalidad de una persona. mundo interior. Los resultados del estudio pueden ser de utilidad para profesores y psicólogos y ser puestos en práctica como parte del asesoramiento psicológico para estudiantes.

Palabras clave: Autoorganización. Actividades de aprendizaje. El establecimiento de metas. Motivación. Planificación. Reflexión.

\section{INTRODUCTION}

Modern Federal State Educational Standards of the 3rd generation (hereafter FSES 3++) orient university teachers towards the formation of students' so-called universal competencies, which must be present in graduates of all directions and profiles of training. Self-organization and self-development belong to the sixth category of universal competencies and refer to the ability to manage one's time and create and realize the trajectory of personal development based on the principles of lifelong learning.

The new conditions of socio-economic development in Russia require that graduates, in addition to possessing professional skills and abilities, be capable of searching for and implementing new, effective forms of organizing their activities. In the situation of uncertainty the role of the student's ability to respond quickly to changing situations, to be ready for continuous education, personal and professional self-improvement, and self-actualization increases. 
Purposefully organized learning activity of students requires a considerable degree of responsibility, diligence, and other volitional personal qualities, as well as the ability to plan and organize one's working day. Learning can be regarded as effective if the student is capable of consciously managing the learning process: correctly formulating educational goals, choosing the individual learning trajectory, valuing their time and using it efficiently, focusing on what is most important, managing their desires, constantly monitoring their personal achievements and evaluating their effectiveness. Thus, self-organization becomes a critical and necessary condition for a person to achieve a new quality of life (educational goals) (Kriucheva, 2016).

The question arises: what exactly is self-organization?

\section{LITERATURE REVIEW}

The term "self-organization" was introduced into science in 1947 by the English scholar W.R. Ashby. The conceptions of self-organization are developed within various branches of science.

In particular, from the point of cybernetics, self-organization is understood as the presence of a predetermined goal, towards which the system seeks to independently maintain or improve its organization, considering the previous experience under changing external and internal conditions (Ishkov, 2015; Kotova, 2010).

The synergetic approach is designed to detect common patterns of self-organization, reveal the mechanisms of the spontaneous emergence and formation of ordered structures and systems. From the point of view of synergetics, the concept of "self-organization" characterizes the process of creation, reproduction, or improvement of a complex dynamic system, the links between the elements of which are not rigid, but probabilistic.

According to N.A. Bernshtein, self-organization (as applied to living systems) reflects not so much "the balancing of the organism with the environment" as overcoming this environment, movement in the direction of the generic program of development and self-sufficiency (Leontiev, 2011) [4]. P.K. Anokhin proceeds from the fact that any living system has an internal organization capable of adequately adapting to the external environment.

Biological processes of self-organization as a factor of self-preservation occur on the reflexive level. The phenomenon of self-reproduction is characteristic both for a single cell and for tissues and the organism as a whole, i.e. for the entire biological world of animals and humans (larygin et al., 2003; Molozhavenko, 2006).

The biological laws of self-organization are expressed in the organism's desire for selfpreservation and are reflected in the social laws of human behavior - in the need for the harmonious integrity of the individual, its self-sufficiency, which brings satisfaction with life.

Psychological and pedagogical literature offers no unified definition of self-organization.

For example, V.I. Dontsov understands self-organization as a person's inner work on themselves that leads to the improvement of the procedural aspect of activity. The ability to selforganization is formed in a purposefully organized activity.

M.I. Diachenko and L.A. Kandybovich (2001) consider self-organization as a set of natural and social properties of personality manifested in intellectual and volitional features and motives of behavior and realized in the orderliness of activity and behavior (Kotova, 2010).

S.S. Amirova (1995) develops a concept and model of intensification of the leading forces of self-organization in continuous professional education. The author understands the system of intellectual, emotional, and moral-volitional character traits as the driving forces behind selforganization. O.N. Kniazkova formulates the scientific understanding of the content of the concept "student's self-organization culture". In her opinion, the development of the model of student's self-organization culture should be based on the idea of using art-pedagogical means and methods in the university educational process, such as the use of fiction, cinema art, and fine art (Smoliar, Kniazkova, 2018). 
L.S. Klentak emphasizes the need to form students' ability to self-organize independent work. She designs a model and formulates pedagogical conditions for the implementation of the system of forming students' abilities to the self-organization of independent work through the use of portfolio technology (Grechnikov, Klentak, 2016).

Based on the theoretical and methodological analysis of the problem under study, we propose our view on self-organization of learning activity, which will be interpreted as a student's purposeful, independent, conscious regulation of their behavior aimed at achieving effectiveness in learning and expressed through correct goal-setting, analysis of their inner potential, and competent planning and control over the results of their activities.

\section{METHODS}

A psychological and pedagogical study was conducted based on the Tyumen Industrial University. Its purpose was to study the level of students' self-organization and to develop the stages of the self-organization of learning. The sample of the experiment was formed by 60 students in the direction of training "Standardization and Metrology" aged from 18 to 20 years old.

To achieve the established goal, the study used the empirical methods of observation, testing, analysis of the results of activity, and conversation. The level of self-organization was assessed using A.D. Ishkov's method "Diagnostics of the features of self-organization-39". This method allowed determining the degree of development of such functional components of selforganization as goal setting, situation analysis, planning, self-monitoring, and correction.

\section{RESULTS}

Based on the results of the questionnaire, a profile of students' self-organization was compiled (Table 1).

Table 1. Self-organization profile

\begin{tabular}{|c|c|c|c|c|c|c|c|c|c|c|}
\hline \multirow[t]{4}{*}{ Scale } & \multicolumn{10}{|c|}{ Level of development } \\
\hline & \multicolumn{2}{|c|}{ Low (\%) } & \multicolumn{2}{|c|}{$\begin{array}{l}\text { Below } \\
\text { average (\%) }\end{array}$} & \multicolumn{2}{|c|}{ Average (\%) } & \multicolumn{2}{|c|}{$\begin{array}{l}\text { Above } \\
\text { average (\%) }\end{array}$} & \multicolumn{2}{|c|}{ High (\%) } \\
\hline & \multicolumn{10}{|c|}{ score } \\
\hline & 1 & 2 & 3 & 4 & 5 & 6 & 7 & 8 & 9 & 10 \\
\hline 1 & 2 & 3 & 4 & 5 & 6 & 7 & 8 & 9 & 10 & 11 \\
\hline Goal-setting & 10 & 5 & 3 & 20 & 13 & 18 & 15 & 2 & 8 & 5 \\
\hline Situation analysis & 8 & 12 & 13 & 22 & 7 & 12 & 18 & 3 & 0 & 5 \\
\hline Planning & 7 & 5 & 20 & 10 & 15 & 5 & 15 & 3 & 8 & 12 \\
\hline Self-monitoring & 5 & 12 & 8 & 20 & 8 & 15 & 7 & 10 & 12 & 3 \\
\hline Correction & 15 & 8 & 10 & 15 & 10 & 7 & 5 & 10 & 8 & 12 \\
\hline $\begin{array}{l}\text { Level of } \begin{array}{r}\text { self- } \\
\text { organization } \\
\text { values) }\end{array} \\
\end{array}$ & \multicolumn{2}{|l|}{8.7} & \multicolumn{2}{|c|}{14.1} & \multicolumn{2}{|c|}{11.0} & \multicolumn{2}{|c|}{8.8} & \multicolumn{2}{|l|}{7.3} \\
\hline
\end{tabular}

Figures 1 and 2 reveal that the majority of the students show the below-average level of selforganization. The respondents do not have a clear idea of what they want to achieve in life. Their actions are situational and do not imply any plan, the students can leave the matter in hand, switching to activities more interesting and meaningful for them. It is difficult for them to adequately evaluate their personal qualities, critically analyze the results of their actions. 


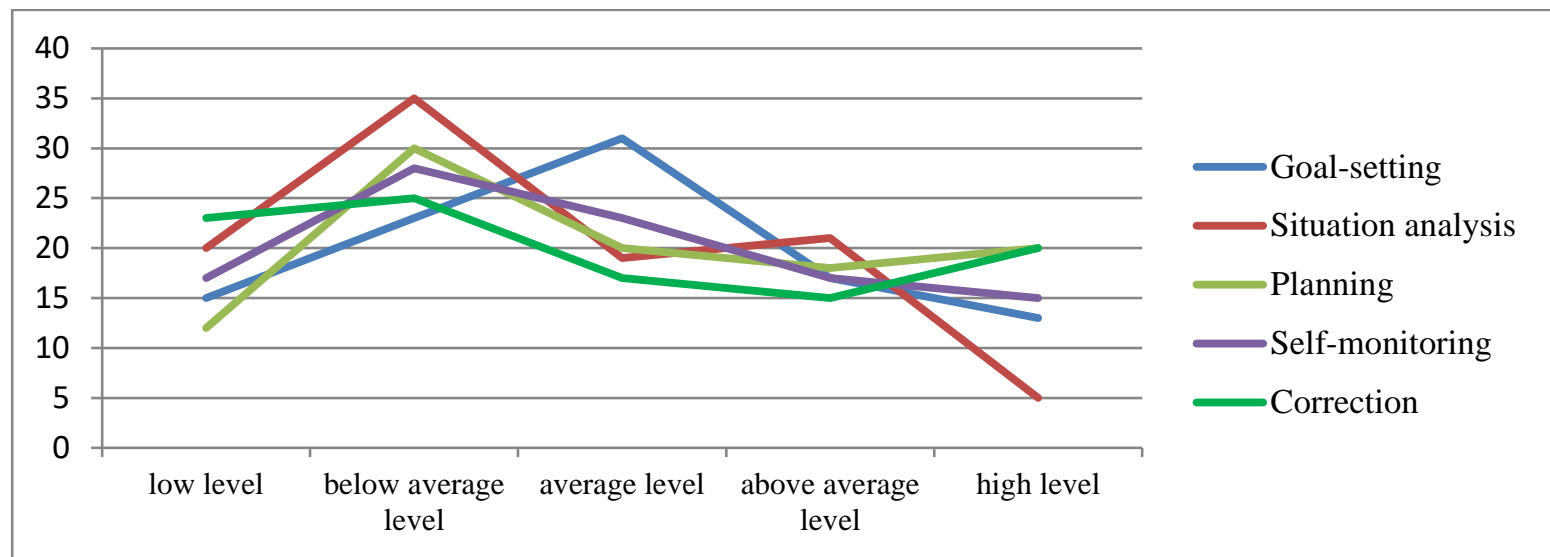

Figure 1. Level of development of self-organization components

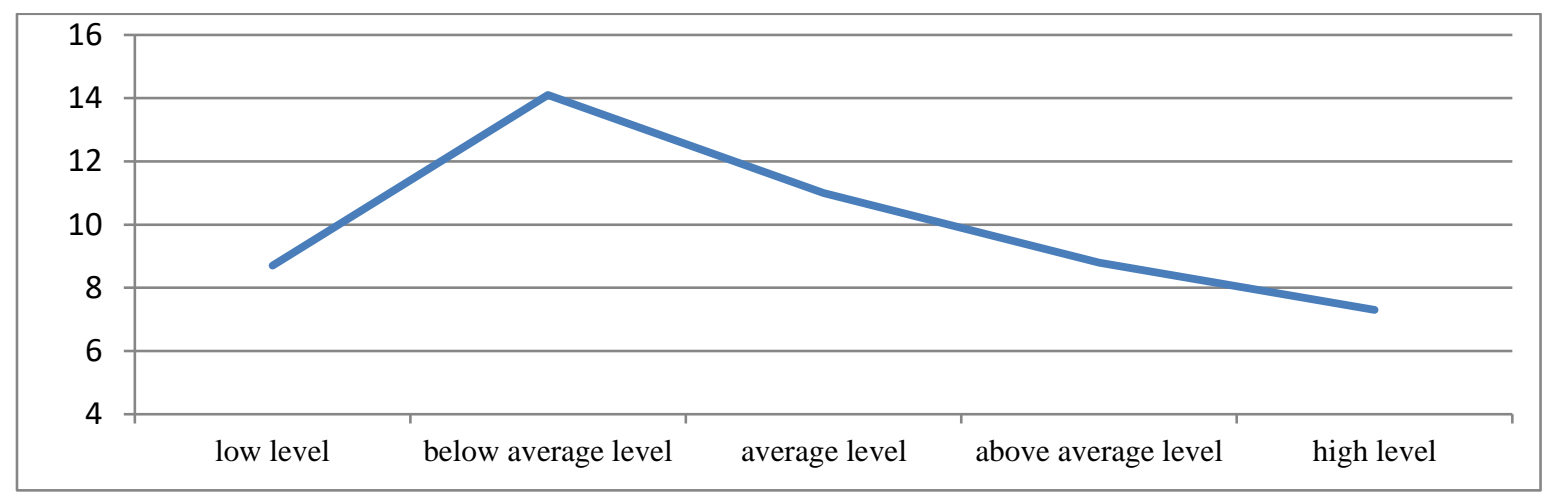

Figure 2. The average overall level of development of organizational skills

Thus, the conducted experimental study of the level of self-organization in the university students reveals the most problematic components - the students demonstrate poor ability to plan and purposefully carry out the activities of the development and self-development of the necessary qualities and skills, as well as to practice self-analysis, self-assessment, and self-monitoring of their plans and time. Thus, the results of the experiment on the study of students' self-organization allow concluding on the need for the development of the UK-6 competency as part of learning activity.

\section{DISCUSSION}

The curricula developed in accordance with FSES $3++$ and the corresponding main Bachelor's degree programs of vocational education include the academic discipline "Fundamentals of selforganization and self-study". The objective of this discipline is to contribute to continuous personality development, to the advancement of a person's independence and organization, to the mobilization of inner capabilities and abilities, to the formation of readiness for learning and constant self-improvement.

Following the structural-functional models of the process of self-organization developed by such authors as O.A. Konopkin, N.M. Peisakhov, la.O. Ustinova, and A.D. Ishkov, we define the following stages of the self-organization of learning in students within the framework of the aforementioned discipline (Figure 3).

The first stage is motivational. This stage involves the search for and establishment of goals, as well as the analysis of the motives behind action. A competently formulated goal allows determining the direction and speed of attaining it. The ability to independently determine the goals of one's life is fundamental for success and career advancement. Motivation is the source of people's activity, which is why it is important to recognize one's motives and rely on them.

At this stage, the academic discipline "Fundamentals of self-organization and self-study" presupposes the following activities and educational tasks: 1 ) the familiarization of students with 
the key concepts: goal, values, and integrity; 2) performing the exercises "Values and Priorities," "If I Had a Million Dollars," and "Life Balance Wheel"; 3) the final exercise is filling out the "Strategy Card," on which students write out their short-term personal goals. Thus, the student formulates a vision of the final results of their actions.

The motivational stage is considered to be completed if the student has pictured what they are going to achieve, what they will have, or who they will become once they make appropriate efforts and actions to achieve the goal.

The second, personality stage presupposes exploring the individual psychological personality characteristics and analyzing the available resources. Students study their temperament, character, abilities, cognitive processes - the peculiarities of memory, thinking, and imagination, which serve as a basis for the realization of goals. The process of learning and becoming aware of their feelings, desires, and needs is critical for personal and professional self-determination and the choice of the right methods and means of solving problems. The knowledge of one's selfesteem depends the level of pretensions and commitment, as well as the adequacy of orientation in the task set before oneself. To act adequately in the chosen developmental trajectory, the learner needs to know what personal qualities they possess, what positive aspects can support them on their way to the result. Critical assessment of one's strengths and weaknesses helps to objectively analyze the reasons underlying the effective and ineffective activity. The students complete the tests "Temperament", "Determination of the peak of your efficiency", "Are you a strong-willed person?", "Are you able to manage your emotions?", "Self-assessment of business communication", and "Your level of sociability".

At the third, practical stage, students proceed to plan their actions, practice some practical methods and techniques. The high level of planning is expressed by the student's ability to independently develop elaborate and detailed plans of their time and think through the order of their actions to achieve the set goals.

Independently carrying out general and partial planning of one's time, covering all or separate details of the plan accordingly, and thinking through the order of one's actions to achieve the goals set is the key to success in achieving the declared result.

As part of this educational task, students perform the following exercises:

1) make a list of all their tasks for the next 10-14 days and categorize them by importance in terms of professional and personal goals into three groups: essential tasks (Category A), important tasks (Category B), and less important non-essential tasks (Category $C$ ). According to the $A B C$ analysis technique, Category $A$ tasks should be performed first to make a greater contribution to the goal with fewer actions.

2) study the method of rigid-flexible planning, the algorithm of which is effective in the case of close deadlines, and develop a personal time plan: a) all rigid tasks are written under a specific time; b) flexible tasks are written in a simple list; c) the flexible tasks are prioritized; d) time is allocated for major tasks from the list of flexible tasks; e) the completed tasks are crossed out.

It is important to keep in mind that the main aspect of the proposed exercises is not so much the completion of the planned work, but rather a conscious understanding of the importance of conceived actions in achieving the desired result.

Written planning has a psychological effect of self-motivation to work and disciplines the student, their activity gains purposefulness and orientation on performing specific actions.

The mastered methods of action, provided by a combination of the acquired knowledge and skills, allow, considering individual characteristics and based on independent and purposeful time planning, to use one's energy rationally and to effectively organize one's life activities, obtaining the desired results.

Thus, time planning is an important element of time management. In addition, the proposed techniques contribute to effective prioritization. 
Monitoring of the results of one's actions is carried out at the next stage - the reflection stage.

The process of self-organization utilizes such types of control as self-monitoring and selfassessment. It is important to note the importance of step-by-step monitoring, which consists in testing the correctness and sequence of steps at each stage of approaching the goal, which allows correcting one's actions promptly. Of no less importance at this stage is self-assessment - evaluation of the organization of work, the performance of work tasks. Self-assessment must be sincere and adequate, reflecting the results of one's steps in a meaningful and qualitative way. Objective selfassessment helps to realistically realize both one's strengths and weaknesses, to set achievable goals, to regulate the level of aspirations, and predict possible obstacles on the way to the set goal.

Self-monitoring contributes to the optimization of the student's personal life, allows them to keep track of their achievements. Successful progress toward the goal creates a sense of satisfaction, which inspires the student and provides sustained motivation; failure creates an opportunity to rethink the chosen strategy and plan new actions. By carrying out self-monitoring over the progress of the plan and assessing the quality of the work performed, students identify possible deviations, eliminating them promptly.

S.D. Reznik suggests using the five-point scale when evaluating the results of the past day (week, year) - how successful or unsuccessful it was, how satisfied with the actual state of affairs one is (Reznik, Igoshina, 2015).

In such reflection, students are assisted by additional questions: "Did I succeed in solving the task I set?", "What opportunities and abilities helped/can help me cope with difficulties?", "What step can I take today to get closer to my main goal in life?", "Am I fighting against 'hindrances', 'time absorbers'?".

The main prerequisite on the way to self-organization is recognizing the existence of the problem of inefficient "living" and disharmonious distribution of time between all aspects of life by means of reflection as a form of active rethinking of certain contents of individual consciousness, activity, communication. Reflexive ability provides for the process of development and selfdevelopment, promotes a creative approach to all types of activity, its maximum efficiency and effectiveness, allows drawing conclusions from past experience, clearly realizing the goal set and foreseeing the result of future activity. On the reflexive-behavioral properties of a person depends the path they will take to achieve the goal, how the process of reconsideration will influence their behavior, and how effective the process of personality development will be.

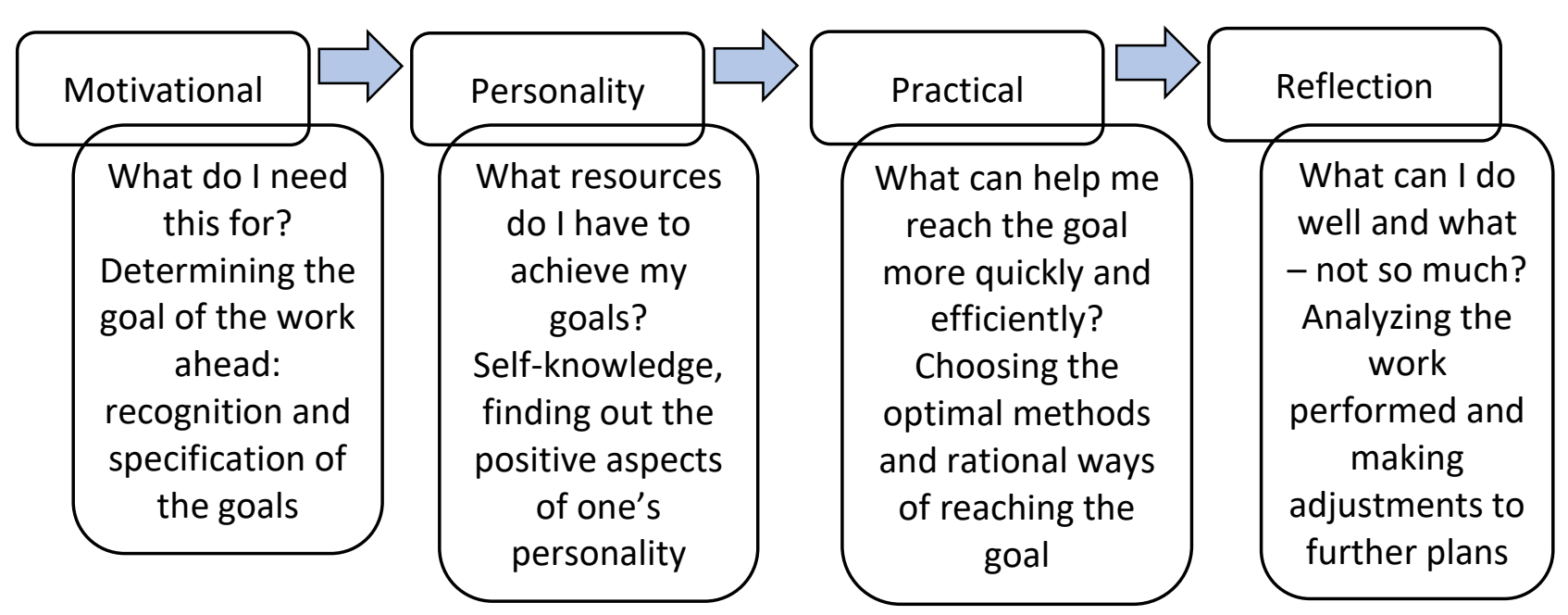

Figure 3. Schematic of the process of self-organization development 


\section{CONCLUSIONS}

A person who purposefully engages in self-knowledge, planning, and organization of their time develops and strengthens the necessary knowledge and skills, the correct value orientations on time and self-development, increases their motivation for self-organization, forms the image of an organized person in the eyes of others, which is subsequently transferred to real life and professional situations.

Concluding the above, we can argue that the discipline "Fundamentals of self-organization and self-study" contributes to the development of students' competencies necessary to increase the efficiency of individual work. The practical orientation of the course allows developing the following skills and abilities in students: rational time management, purposeful and competent planning of action, objective assessment, timely correction, and improvement of the process and results of one's work. Consistent passage of all stages of self-organization allows becoming more conscious of independent learning activities and increases their importance.

Authors' Contributions: Kryucheva, Y.V.: conception and design, acquisition of data, analysis and interpretation of data, drafting the article, critical review of important intellectual content. Tolstoukhova, I.V.: conception and design, acquisition of data, analysis and interpretation of data, drafting the article, critical review of important intellectual content. All authors have read and approved the final version of the manuscript".

Ethics Approval: Not applicable.

Acknowledgments: Not applicable.

\section{REFERENCES}

Amirova, S.S. (1995). Samoorganizatsiia obuchaiushchego i obuchaemogo v uchebno-vospitatelnom protsesse nepreryvnogo professionalnogo obrazovaniia [Self-organization of the student and the teacher in the learning and upbringing process of continuous professional education]: summary of a doctoral dissertation in pedagogy. Kazan: Kazan Pedagogical University.

Grechnikov, F.V., Klentak, L.S. (2016). Vliianie metoda formirovaniia portfolio na effektivnoe ispolzovanie vremeni studentami vuza [The effect of the portfolio method on the effective time management of university students]. Integration of Education, 20(1(82)), 88-96.

larygin, V.N., Vasileva, V.I., Volkov, I.N., Sinelytsikova, V.V., larygin, V.N. (2003). Biologiia [Biology]. In 2 books. Book 1. Moscow: Vysshaya shkola.

Ishkov, A.D. (2015). Uchebnaia deiatelnost studenta: psikhologicheskie faktory uspeshnosti [Academic activity of a student: psychological factors of success]. Moscow: ASV Publishing house.

Kotova, S.S. (2010). Osnovy effektivnoi samoorganizatsii. [Fundamentals of effective self-organization]. Yekaterinburg: Publishing house of the State Educational Institution of Higher Vocational Education "Russian State Vocational Pedagogical University".

Kriucheva, Ia.V. (2016). Samosovershenstvovanie studentov tekhnicheskogo vuza [Self-improvement of students of a technical university]. Science Review: Humanities Research, 11, 128-133.

Leontiev, D.A. (2011). Samoorganizatsiia zhivykh sistem kak uslovie ikh vosproizvodstva [Self-organization of living systems as a condition for their reproduction]. Mir psikhologii, 2, 16-27.

Molozhavenko, V.L. (2006). Samoorganizatsiia - tvorcheskii protsess samostroitelstva lichnosti [Self-organization - the creative process of self-construction of personality]. Tyumen: Tyumen State Oil and Gas University.

Reznik, S.D., Igoshina, I.A. (2015). Student vuza: tekhnologii i organizatsiia obucheniia v vuze [University student: the technology and organization of learning in higher education]. Moscow: INFRA-M.

Smoliar, A.I. Kniazkova, O.N. (2018). Razvitie kultury samoorganizatsii lichnosti studenta vuza sredstvami artpedagogiki [The development of students' personality self-organization culture by means of art-pedagogy]. Samara: 
Samara State University of Social Sciences and Education.

Received: 31 August 2021 | Accepted: 22 December 2021 | Published: 29 January 2022 